\title{
Hubungan Kepatuhan Minum Obat Anti Diabetik dengan Regulasi Kadar Gula Darah pada Pasien Perempuan Diabetes Mellitus
}

\section{Relationship between Antidiabetic Drugs Consumption and Blood Glucose Level Regulation for Diabetes Mellitus Female Patients}

\author{
Oryza Dwi Nanda*1, R. Bambang Wiryanto², Erwin Astha Triyono ${ }^{3}$
}

\begin{abstract}
ABSTRAK
Latar Belakang: Pengendalian kadar gula darah merupakan hal yang penting dalam penanganan diabetes melitus. Pasien diabetes perlu memahami faktor-faktor yang mempengaruhi pengendalian kadar gula darah salah satunya adalah kepatuhan minum obat anti diabetik.

Tujuan: Mengetahui hubungan dan besar risiko kepatuhan minum obat oral anti diabetik dengan regulasi kadar gula darah pada pasien perempuan diabetes mellitus.

Metode: Desain penelitian kasus kontrol dengan teknik purposive sampling, sehingga diperoleh 26 sampel penelitian yang terdiri dari dua kelompok yaitu kelompok kasus (gula darah tidak teregulasi) sebanyak 13 dan kelompok kontrol (gula darah teregulasi) sebanyak 13 responden perempuan berusia 45-59 tahun yang menderita diabetes melitus. Hubungan dan besar risiko kepatuhan minum obat anti diabetik dengan regulasi gula darah pasien diabetes mellitus menggunakan uji chi-square.

Hasil: Pasien dengan gula darah tidak teregulasi menunjukkan sebanyak $46,2 \%$ patuh dan $53,8 \%$ tidak patuh dalam minum obat anti diabetik. Pasien dengan gula darah teregulasi menunjukkan sebanyak 92,3\% patuh dan 7,7\% tidak patuh dalam minum obat anti diabetik. Uji chi square menunjukkan terdapat hubungan antara kepatuhan minum obat anti diabetik dengan regulasi kadar gula darah pada pasien diabetes melitus dengan nilai $p=0,015$ dan nilai OR sebesar 14 dengan $\mathrm{Cl}$ 95\% (1,385-141,485) yang berarti responden yang tidak patuh minum obat anti diabetik berisiko 14 kali mengalami regulasi gula darah yang buruk dibandingkan dengan pasien yang patuh dalam minum obat anti diabetik.

Kesimpulan: Terdapat hubungan antara kepatuhan minum obat anti diabetik dengan regulasi gula darah pada pasien perempuan rawat jalan usia 45-59 tahun di Puskesmas Mojo, Pucang Sawu, dan Keputih Surabaya. Pasien dengan kadar gula darah tidak terkontrol lebih banyak tidak patuh dalam minum obat anti diabetik, sedangkan pada pasien dengan gula darah terkontrol sebagian besar cukup patuh dalam minum obat anti diabetik.
\end{abstract}

Kata Kunci: diabetes melitus, kepatuhan minum obat, dan regulasi gula darah.

\section{ABSTRACT}

Background: Blood glucose level controlling is the important thing for diabetes mellitus treatment. Diabetics patients need to understand the factors which influence blood glucose level such as the compliance of anti-diabetic drug.

Objective: Determine the relationship and the risk of between oral anti-diabetic drug consumption adherence and blood glucose level regulation for diabetes mellitus female patients.

Method: Case control study design with purposive sampling technique, in order to obtain 26 research samples which consist of two groups, they are case group (unregulated blood glucose) which has 13 samples and the control group (regulated blood glucose) whice has 13 samples. The samples are female respondents aged 45-59 years old suffering diabetes mellitus. This research analyzed the relationship 
and risk between anti-diabetic consumption adherence and blood glucose level regulation in diabetes mellitus patients using chi-square test.

Results: Patients with unregulated blood glucose showed $46.2 \%$ people were obedient and $53.8 \%$ were not obedient in consuming anti-diabetic drugs. Patients with regulated blood glucose showed $92.3 \%$ people were obedient and $7.7 \%$ people were not obedient in consuming anti-diabetic drugs. Chi square test showed that there was a relationship between anti-diabetic drugs consumption adherence and blood glucose level regulstion for diabetes mellitus patients with $p=0.015(p<0.05)$ and an OR value of 14 with a $95 \% \mathrm{Cl}(1.385-141.485)$, which means that unobedient have 14 times risker suffered terrible blood glucose regulation than obedient patients.

Conclusion: There was a relationship between anti-diabetic drug consumption adherence and blood glucose level regulation in female patients aged 45-59 years in Mojo Health Center, Pucang Sawu, and Keputih Surabaya. Patients with uncontrolled blood sugar level are more disobedient in consuming antidiabetic drugs. Meanwhile, patients with controlled blood glucose were most obedient people in consuming anti-diabetic drugs.

Keywords: Diabetes mellitus, adherence to taking anti-diabetic drugs, and blood glucose regulation

\author{
*Koresponden: \\ oryzawnanda01@gmail.com \\ ${ }^{1}$ Departemen Gizi Kesehatan, Fakultas Kesehatan Masyarakat Universitas Airlangga \\ ${ }^{2}$ Rumah Sakit Umum Dr. Soetomo, Surabaya, Jawa Timur
}

\section{PENDAHULUAN}

Secara global telah terjadi perubahan pola penyakit, yaitu dari penyakit menular menjadi penyakit tidak menular. Penyakit tidak menular saat ini, masuk ke dalam sepuluh besar penyebab kematian terbanyak secara nasional, salah satunya adalah diabetes melitus (DM). ${ }^{1}$ Diabetes melitus adalah penyakit metabolik yang ditandai dengan kenaikan gula darah atau hiperglikemia yang disebabkan oleh kelainan sekresi insulin, gangguan kerja insulin, maupun keduanya. ${ }^{2}$ Prevalensi diabetes di dunia mencapai 230 juta penduduk dan angka tersebut naik sebesar $3 \%$ atau bertambah 7 juta jiwa setiap tahun. ${ }^{3}$ Tahun 2025 diperkirakan akan ada 350 juta orang yang mengalami diabetes melitus di dunia. WHO menyebutkan bahwa separuh dari penderita diabetes dewasa di dunia berada di 5 negara, yaitu China, India, Amerika Serikat, Brazil, dan Indonesia. ${ }^{3}$

Indonesia menduduki peringkat ke-7 jumlah pengidap diabetes mellitus tertinggi di dunia. International Diabetes Federation (IDF) menyebutkan bahwa pada tahun 2016 Indonesia memiliki sekitar 9,1 juta pengidap DM. ${ }^{4}$ Diperkirakan jumlah tersebut dapat meningkat menjadi 12,4 juta orang pada tahun 2025 dan mencapai 14,1 juta orang pada tahun
2035. ${ }^{3}$ Salah satu wilayah dengan jumlah penderita diabetes terbanyak adalah Provinsi Jawa Timur dengan prevalensi penderita DM yaitu sebesar $2,1 \%$, yang masuk dalam urutan 10 besar yaitu pada urutan kelima prevalensi penderita diabetes mellitus se-Indonesia. ${ }^{5}$ Hampir $10 \%$ penduduk di kota Surabaya merupakan pengidap $\mathrm{DM}^{3}$. Gaya hidup di Kota Surabaya cenderung tinggi lemak, garam, gula, dan makanan instan yang dapat menyebabkan peningkatan kadar gula darah. ${ }^{6}$ Prevalensi DM pada perempuan lebih tinggi daripada laki-laki, terutama pada DM tipe 2, karena lebih mudah mengalami obesitas akibat kenaikan indeks masa tubuh yang lebih besar, mengalami siklus bulanan/menstruasi, dan menopause sehingga lebih mudah mengalami penimbunan lemak di dalam tubuh karena proses hormonal. ${ }^{7}$ Risiko DM meningkat terutama ketika seseorang berusia 45 tahun ke atas dan mengalami kelebihan berat badan, sehingga tubuh tidak sensitif lagi dengan insulin. ${ }^{8}$

Pengendalian kadar gula darah merupakan hal yang penting dalam penanganan DM. Pasien diabetes perlu memahami faktor-faktor yang berpengaruhi untuk mengendalikan kadar gula darah, yaitu diet, aktivitas fisik, kepatuhan minum obat, dan pengetahuan. ${ }^{9}$ Keberhasilan pengelolahaan DM untuk mencegah komplikasi dapat dicapai 
salah satunya melalui kepatuhan dalam terapi farmakologi. Kepatuhan merupakan perubahan perilaku sesuai perintah yang diberikan dalam bentuk terapi latihan, diet, pengobatan, maupun kontrol penyakit kepada dokter. Secara tidak langsung, tingkat kepatuhan minum obat dapat diukur dengan kuesioner Morisky Medication Adherence Scale (MMAS)-8. Kuesioner tersebut merupakan metode untuk menilai kepatuhan pengobatan pada pasien dengan penyakit kronis, termasuk diabetes yang sudah divalidasi oleh WHO. Ketidakpatuhan minum obat dapat mengakibatkan komplikasi, risiko rawat inap, dan biaya yang tinggi. ${ }^{10}$ Penelitian Cahyo Widodo, dkk tahun 2016 menyatakan bahwa berdasarkan hasil uji chi square, terdapat hubungan kepatuhan konsumsi obat anti glikemik dengan kadar gula darah pasien DM di Fasyankes Primer Klaten dengan $p$ value 0,006. ${ }^{11}$ Pada penelitian tersebut pada kelompok gula darah terkontrol memiliki kepatuhan tinggi hingga sedang, sedangkan pada kelompok gula darah tidak terkontrol lebih banyak memiliki kepatuhan minum obat yang rendah. WHO melaporkan bahwa ratarata kepatuhan pasien dalam menjalankan terapi jangka panjang penyakit kronis di negara berkembang masih rendah, sedangkan di negara maju mencapai $50 \% .{ }^{12}$ Keberhasilan pengobatan dapat dibuktikan dengan hasil laboratorium cek glukosa darah puasa mengalami penurunan menjadi $70-130 \mathrm{mg} / \mathrm{dl}$. Berdasarkan uraian yang telah dipaparkan, maka penelitian ini bertujuan untuk mengetahui hubungan kepatuhan minum obat oral anti diabetik dengan regulasi kadar gula darah pasien DM di Puskesmas Mojo, Pucang Sewu, dan Keputih, Kota Surabaya.

\section{METODE}

Penelitian ini menggunakan desain studi kasus kontrol yang dilaksanakan di Puskesmas Mojo, Pucang Sewu, dan Keputih Surabaya pada bulan Mei hingga Agustus 2018. Populasi terjangkau yang digunakan adalah semua pasien DM di 3 puskesmas tersebut yang berobat dari bulan Januari hingga Juni 2018, yaitu sebanyak 901 orang. Kriteria inklusi penelitian yaitu, pasien DM perempuan rawat jalan berusia 45-59 tahun, memiliki rekam medik lengkap terkait pemeriksaan gula darah rutin, dan bersedia menjadi responden penelitian. Metode pengambilan sampel adalah non random sampling dengan teknik purposive sampling yang merupakan teknik pengambilan sampel dengan beberapa pertimbangan tertentu yang dilakukan oleh peneliti. ${ }^{13}$ Besar Sampel dihitung menggunakan rumus besar sampel dari Kuntoro tahun 2010 dengan $\mathrm{Cl}$ sebesar 1,96 dan power sebesar 1,28 sehingga didapatkan jumlah sampel sebanyak 26 orang, yaitu 13 responden kasus dan 13 responden kontrol. ${ }^{14}$

Kriiteria responden sebagai kelompok kasus (tidak teregulasi) merupakan pasien perempuan rawat jalan yang menderita DM usia 45-59 tahun dengan kadar gula darah puasa $(\mathrm{GDP}) \geq 126 \mathrm{mg} / \mathrm{dl}$. Kelompok kontrol (teregulasi) merupakan pasien perempuan rawat jalan yang menderita diabetes mellitus usia 45-59 tahun dengan kadar gula darah puasa (GDP) $<126 \mathrm{mg} / \mathrm{dl}$. Kepatuhan minum obat ditentukan melalui kuesioner 8-item structure dari Morisky (MMAS-8) yang terdiri dari pertanyaan lupa minum obat $(1,4,8)$, tidak minum obat $(2,5)$, berhenti minum obat $(3,6)$, terganggu karena jadwal minum obat (7). Kriteria penilaian jika jawaban ya=0, tidak $=1$, dan skala likert (tidak pernah=4, sesekali $=3$, terkadang $=2$, biasanya $=1$, setiap waktu=0). Kepatuhan minum obat dikategorikan dalam 2 penilaian yaitu patuh (nilai $=\geq 6$ ) dan tidak patuh (nilai $=<6$ ). ${ }^{15}$

Penelitian ini menggunakan dua metode pengambilan data, yaitu pengambilan data tidak langsung dan langsung. Pengambilan data tidak langsung bertujuan untuk menentukan kriteria sampel kasus dan kontrol pada responden dengan melihat gula darah puasa pada rekam medik pasien. Pengambilan data secara langsung menggunakan metode wawancara dengan kuesioner dan pengukuran status gizi menggunakan timbangan digital kabuto EB 8018 dengan ketelitian 0,1 dan microtoise. Karakteristik responden yang dinilai adalah usia, tingkat pendidikan, pendapatan, dan status gizi. Status gizi ditentukan berdasarkan 3 kategori yaitu kategori Kurus (IMT $<18,5$ ), normal (IMT $>18,5$ 22,9), dan obesitas (IMT>23,0). ${ }^{16}$

Data yang diperoleh akan dianalisis secara bivariat untuk menganalisis hubungan 
dan besar risiko menggunakan uji chi-square. Penelitian ini telah mendapatan persetujuan etik dari Komisi Etik Fakultas Kesehatan Masyarakat Universitas Airlangga Surabaya dengan Nomor 449 tanggal 24 Juli 2018.

\section{HASIL DAN PEMBAHASAN}

Perempuan memiliki risiko tinggi mengalami DM dibandingkan laki-laki. ${ }^{7} \mathrm{Hal}$ tersebut disebabkan karena perempuan mengalami masa pra menopause dan menopause, serta ditambah faktor-faktor lain seperti gaya hidup, kurang aktifitas fisik, faktor stres, dan lainnya. ${ }^{7}$

Risiko tersebut akan meningkat ketika seseorang berusia diatas 45 tahun karena tubuh telah mengalami proses penuaan. Rerata usia responden paling banyak adalah pada masa middle age yaitu usia 51-55 tahun. Usia tersebut merupakan usia pertengahan yang menampakkan kematangan jiwa dan merupakan masa persiapan usia lanjut.

Selain jenis kelamin dan usia, status gizi lebih atau obesitas juga merupakan risiko terjadinya DM.

Tabel 1. Karakteristik Responden berdasarkan usia, status gizi, tingkat pendidikan, pendapatan.

\begin{tabular}{|c|c|c|c|c|}
\hline \multirow{2}{*}{ Karakteristik Responden } & \multicolumn{2}{|c|}{ Tidak Teregulasi } & \multicolumn{2}{|c|}{ Teregulasi } \\
\hline & $n$ & $\%$ & $\mathbf{n}$ & $\%$ \\
\hline \multicolumn{5}{|l|}{ Usia } \\
\hline 45-50 tahun & 2 & 15,4 & 1 & 7,7 \\
\hline 51-55 tahun & 7 & 53,8 & 7 & 53,8 \\
\hline 56-59 tahun & 4 & 30,8 & 5 & 38,5 \\
\hline \multicolumn{5}{|l|}{ Status Gizi } \\
\hline Kurus & 0 & 0 & 0 & 0 \\
\hline Normal & 2 & 15,4 & 1 & 7,7 \\
\hline Obesitas & 11 & 84,6 & 12 & 92,3 \\
\hline \multicolumn{5}{|l|}{ Tingkat Pendidikan } \\
\hline Tidak Tamat SD & 1 & 7,7 & 6 & 46,1 \\
\hline Tamat SD & 3 & 23,1 & 4 & 30,8 \\
\hline Tamat SMP & 2 & 15,3 & 1 & 7,7 \\
\hline Tamat SMA & 3 & 23,1 & 1 & 7,7 \\
\hline Tamat PT & 4 & 30,8 & 1 & 7,7 \\
\hline \multicolumn{5}{|l|}{ Pekerjaan } \\
\hline Tidak Bekerja & 9 & 69,2 & 10 & 76,9 \\
\hline Bekerja & 4 & 30,8 & 3 & 23,1 \\
\hline \multicolumn{5}{|l|}{ Pendapatan } \\
\hline Rendah (>1juta) & 8 & 61.5 & 5 & 38.5 \\
\hline Sedang (1-2juta) & 3 & 23.1 & 5 & 38.5 \\
\hline Tinggi (>2juta) & 2 & 15.4 & 3 & 23 \\
\hline
\end{tabular}

Tabel 2. Hubungan Kepatuhan minum obat anti diabetik

\begin{tabular}{|c|c|c|c|c|c|c|c|}
\hline \multirow{2}{*}{$\begin{array}{l}\text { Kepatuhan minum obat } \\
\text { anti diabetik }\end{array}$} & \multicolumn{2}{|c|}{ Tidak Teregulasi } & \multicolumn{2}{|c|}{ Teregulasi } & \multirow{2}{*}{ p-value } & \multirow{2}{*}{ OR } & \multirow{2}{*}{ Cl 95\% } \\
\hline & $\mathrm{n}$ & $\%$ & $n$ & $\%$ & & & \\
\hline Tidak Patuh & 7 & 53,8 & 1 & 7,7 & & 11 & $1,385-$ \\
\hline Patuh & 6 & 46,2 & 12 & 92,3 & o & 14 & 141,485 \\
\hline
\end{tabular}

Signifikansi berdasarkan uji Chi Square dengan $p$-value $<0,05$ 
Tabel 3. Alasan ketidakpatuhan pasien

\begin{tabular}{lcccccccc}
\hline \multirow{2}{*}{ Alasan Ketidakpatuhan } & \multicolumn{2}{c}{ Tidak Teregulasi } & \multicolumn{2}{c}{ Teregulasi } & \multicolumn{2}{c}{ Total } & $\boldsymbol{p}$ \\
\cline { 2 - 7 } & Jumlah & $\%$ & Jumlah & $\%$ & Jumlah & $\%$ & Value \\
\hline Lupa & 9 & 69,2 & 4 & 30,8 & 13 & 50 & 0,117 \\
Sengaja tidak meminum obat & 5 & 38,5 & 1 & 7,7 & 6 & 23,1 & 0,080 \\
$\begin{array}{l}\text { Kondisi bertambah parah } \\
\text { Lupa membawa obat saat }\end{array}$ & 3 & 23,1 & 0 & 0 & 3 & 11,5 & 0,110 \\
$\begin{array}{l}\text { berpergian } \\
\text { Kemarin tidak minum obat }\end{array}$ & 6 & 46,2 & 1 & 7,7 & 7 & 26,9 & 0,037 \\
$\begin{array}{l}\text { Merasa sehat } \\
\text { Terganggu oleh keharusan } \\
\text { minum obat }\end{array}$ & 3 & 15,4 & 5 & 38,5 & 7 & 26,9 & 0,189 \\
& 5 & 38,5 & 3 & 23,1 & 6 & 23,1 & 0,678 \\
\hline
\end{tabular}

Signifikansi berdasarkan uji Chi Square dengan $p$-value $<0,05$

Berdasarkan pada tabel 1, jumlah responden yang mempunyai status gizi kurus tidak ada, sebaliknya mayoritas responden pada kelompok kasus $(84,6 \%)$ dan kontrol (92,3\%) mengalami obesitas (IMT>23,0). Diabetes sering muncul setelah seseorang memasuki usia rawan dan mengalami kelebihan berat badan atau obesitas, sehingga tubuh tidak peka lagi terhadap insulin. ${ }^{3}$

Obesitas merupakan faktor risiko yang penting untuk diperhatikan, semakin banyak lemak yang ada dalam tubuh maka jaringan tubuh dan otot akan lebih resisten terhadap kerja insulin, hal tersebut lebih berisiko ketika seseorang mengalami obesitas sentral atau jaringan lemak yang terkumpul di daerah sentral atau perut. Lemak dapat memblokir kerja insulin yang mengakibatkan glukosa dalam darah tidak dapat diangkut masuk ke dalam sel dan menumpuk pada peredaran darah. $^{3}$

Faktor risiko lainnya adalah tingkat pendidikan, tabel 1 menunjukkan tingkat pendidikan sebagian besar responden yang rendah, yaitu tidak tidak tamat SD. Tingkat pendidikan memengaruhi proses belajar seseorang, semakin tinggi pendidikan yang diperoleh maka semakin mudah orang tersebut mendapat informasi, dan semakin banyak informasi yang diperoleh maka akan semakin banyak pula pengetahuan yang didapat. ${ }^{17}$ Pendidikan tinggi yang diperoleh diharapkan dapat membuat seseorang berperilaku lebih sehat dan dapat mencegah penyakit (salah satunya DM) serta dapat menghindari faktor-faktor risikonya. Individu dengan pendidikan tinggi berhubungan signifikan dengan rendahnya risiko untuk mengalami DM dibandingkan yang berpendidikan rendah, karena melalui pendidikan tinggi akan memiliki informasi yang lebih banyak terkait faktor risiko terjadinya DM dan melakukan pencegahan. Jenis pekerjaan menentukan risiko dari DM, jenis pekerjaan akan memengaruhi tingkat aktivitas fisik dan stres, dimana stres akan menyebabkan peningkatan hormon epinefrin yang dapat menyebabkan mobilisasi glukosa, asam lemak, dan asam laktat. Hormon epinefirn adalah hormon antagonis insulin sehingga menghambat kerja insulin dan dapat mempengaruhi kadar gula darah seseorang. ${ }^{2}$

Hasil wawancara diperoleh bahwa kebanyakan responden adalah ibu rumah tangga, sehingga mereka tidak bekerja. Pendapatan seseorang juga merupakan faktor risiko dalam kejadian diabetes dan pengaturan pola makan. Orang yang memiliki pendapatan tinggi cenderung lebih rentan terkena diabetes mellitus terutama tipe 2, karena perubahan sosial ekonomi dan pergeseran gaya hidup dalam hal konsumsi makanan terutama dipengaruhi karena peningkatan pendapatan, kesibukan kerja yang tinggi, dan promosi trend makanan barat, utamanya fast food yang populer di Amerika dan Eropa, yang tidak diimbangi dengan pengetahuan dan kesadaran gizi. Akhirnya menyebabkan tingginya konsumsi lemak jenuh, gula, rendah serat, dan rendah zat gizi mikro. Keadaan tersebut menyebabkan masalah obesitas dan meningkatnya radikal bebas yang menyebabkan terjadinya diabetes mellitus tipe 2. ${ }^{6}$ Tabel 1 menunjukkan bahwa mayoritas responden memiliki pendapatan kurang dari 1 juta setiap bulannya atau tergolong rendah. 
Berdasarkan tabel 2, pasien dengan gula darah tidak teregulasi menunjukkan sebanyak 46,2\% patuh dan 53,8\% tidak patuh dalam minum obat anti diabetik. Pasien dengan gula darah teregulasi menunjukkan sebanyak $92,3 \%$ patuh dan $7,7 \%$ tidak patuh dalam minum obat anti diabetik. Berdasarkan analisis dengan uji chi square terdapat hubungan antara kepatuhan minum obat anti diabetik dengan regulasi kadar gula darah pada pasien diabetes mellitus dengan nilai $p=0,015(p<0,05)$. Analisis besar risiko didapatkan nilai OR sebesar 14 dengan $\mathrm{Cl} 95 \%(1,385-141,485)$ yang berarti responden yang tidak patuh minum obat anti diabetik berisiko 14 kali mengalami regulasi gula darah yang tidak terkontrol dibandingkan dengan responden yang patuh minum obat anti diabetik. Nilai odds ratio tersebut menunjukkan bahwa semakin patuh pasien dalam minum obat anti diabetik, gula darahnya akan semakin terkontrol, namun jika pasien tidak patuh dalam minum obat anti diabetik maka sebaliknya, gula darahnya menjadi tidak terkontrol. Hasil penelitian ini sejalan dengan penelitian sebelumnya, yaitu ada hubungan antara minum obat hipoglikemik oral atau obat anti diabetik dengan kontrol gula darah pada pasien diabetes rawat jalan di RS Bhakti Wira Tamtama Semarang. ${ }^{18}$

Tabel 3 menunjukkan alasan ketidakpatuhan pasien dalam minum obat. Ketidakpatuhan pasien pada kelompok gula darah tidak terkontrol adalah 69,2\% lupa mengkonsumsi obat, $38,5 \%$ sengaja tidak minum obat, $23,1 \%$ tidak minum obat karena merasa kondisinya bertambah parah, $46,2 \%$ lupa membawa obat saat berpergian, 15,4\% tidak mengkonsumsi obat saat dilakukan wawancara, $23,1 \%$ tidak mengkonsumsi obat karena merasa sehat, dan $38,5 \%$ merasa terganggu oleh keharusan minum obat. Ketidakpatuhan pasien pada kelompok gula darah terkontrol adalah $30,8 \%$ lupa mengkonsumsi obat, $7,7 \%$ sengaja tidak minum obat, $7,7 \%$ lupa membawa obat saat berpergian, $38,5 \%$ tidak mengkonsumsi obat saat dilakukan wawancara, $23,1 \%$ tidak mengkonsumsi obat karena merasa sehat, dan 23,1\% merasa terganggu oleh keharusan minum obat. Alasan pasien kadang-kadang lupa minum obat disebabkan karena daya ingat pada pasien yang cenderung menurun akibat bertambahnya usia. Alasan pasien merasa terganggu dengan adanya kewajiban untuk minum obat karena merasa bosan dengan kewajiban rutin tersebut, alasan lain kesengaja tidak minum obat karena merasa sehat adalah pasien mengaku bahwa tidak ingin tergantung dengan obat-obatan dan merasa takut mengalami gangguan pada ginjal jika memiliki kebiasaan minum obat-obatan, oleh karena hal tersebut pasien lebih beralih kepada pengobatan tradisional, seperti penggunaan kayu manis, bawang putih, daun salam, dan mengkudu. Alasan pasien merasa kondisinya bertambah parah karena pasien mengalami alergi ketika minum obat anti diabetik dan merasakan efek samping seperti perasaan tidak nyaman pada perut, sehingga pada akhirnya pasien berhenti untuk minum obat. Obat anti diabetik seperti glimepirid, metformin, dan akarbosa memiliki beberapa efek samping seperti rasa tidak nyaman pada perut dan dapat mengakibatkan kembung atau diare. Berdasarkan hasil uji hubungan pada pernyataan kuisioner terkait alasan kepatuhan pasien dalam mengkonsumsi obat, terdapat hubungan yang signifikan pada pernyataan bahwa pasien lupa membawa obat saat berpergian dengan regulasi gula darah berdasarkan nilai $p$ value sebesar 0,037 . Pasien dengan kadar gula darah teregulasi merasa memiliki tanggungjawab yang lebih terhadap kesembuhannya dan pasien meminimalkan risiko lupa minum atau membawa obat saat berpergian, sehingga hal tersebut yang membuat pasien dengan kadar gula darah teregulasi lebih patuh minum obat.

Kepatuhan minum obat anti diabetik mempengaruhi kadar gula darah pasien, oleh sebab itu kepatuhan minum obat anti dabetik dapat menjadi pilihan pasien dalam mengendalikan gula darahnya. ${ }^{19}$ Pada penelitian ini kepatuhan konsumsi obat anti diabetik pada obat metformin dan glimepiride dapat mengontol gula darah pasien diabetes melitus. Metformin merupakan obat anti diabetik pilihan utama bagi penderita yang gemuk, disertai dislipidemia, dan resistensi insulin yang berfungsi untuk menurunkan resistensi insulin dan mengurangi produksi glukosa hati. Glimepiride merupakan obat golongan sulfonilurea yang berfungsi untuk meningkatkan sekresi insulin oleh sel beta 
pankreas. ${ }^{20}$ Kepatuhan minum obat merupakan hal yang penting bagi penderita diabetes melitus untuk mencapai sasaran pengobatan dan pencegahan komplikasi secara efektif. Terapi pengobatan yang baik dan benar akan sangat menguntungkan bagi pasien diabetes terutama bagi pasien yang yang diwajibkan mengkonsumsi obat dalam waktu lama dan seumur hidup. ${ }^{21}$ Perilaku tidak patuh dapat meningkatkan risiko dan memperburuk penyakit yang diderita. Menurut data WHO, rendahnya tingkat kepatuhan minum obat pada pasien diabetes dipengaruhi oleh beberapa faktor, yaitu karakteristik pengobatan dan penyakit (durasi penyakit, kompleksitas terapi, dan pemberian perawatan), faktor intrapersonal (jenis kelamin, usia, stres, rasa percaya diri, depresi, dan penggunaan alkohol), faktor interpersonal (hubungan pasien dengan petugas kesehatan dan dukungan sosial), dan faktor lingkungan. ${ }^{12}$ Pada penelitian ini, faktor yang berpengaruh berkaitan dengan faktor pengobatan dan penyakit terkait durasi penyakit yang lama sehingga pasien terganggu dengan kewajiban mengkonsumsi obat dan faktor intrapersonal terkait rasa percaya diri yang berhubungan dengan faktor interpersonal terkait dukungan keluarga. Keadaan pasien yang sering lupa mengkonsumsi atau membawa obat saat bepergian dimungkinkan dapat dipengaruhi karena kurangnya dukungan dari keluarga untuk mengingatkan. Keluarga memiliki peranan penting dalam memberikan motivasi, support system, dan perawatan pada anggota keluarga yang merupakan pasien diabetes. ${ }^{22}$

Kelemahan dalam penelitian ini adalah keterbatasan dalam pengambilan sampel penelitian yang mempunyai kadar gula darah terkontrol (GDP $<126 \mathrm{mg} / \mathrm{dl}$ ), sehingga jumlahnya terbatas. Kelebihan dalam penelitian ini adalah belum banyak penelitian serupa yang menggunakan kasus kontrol yang membandingkan kelompok kasus yaitu pasien diabetes dengan gula darah tidak terkontrol (GDP $\geq 126 \mathrm{mg} / \mathrm{dl}$ ) dan kelompok kontrol dengan gula darah terkontrol (GDP<126mg/dl).

\section{KESIMPULAN}

Berdasarkan hasil penelitian dapat disimpulkan bahwa terdapat hubungan antara kepatuhan minum obat oral anti diabetik dengan regulasi gula darah pada pasien perempuan rawat jalan usia 45-59 tahun di Puskesmas Mojo, Pucang Sawu, dan Keputih Surabaya. Pasien dengan kadar gula darah tidak terkontrol kebanyakan tidak patuh dalam minum obat anti diabetik, sedangkan pada pasien dengan gula darah terkontrol sebagian besar patuh dalam minum obat anti diabetik. Obat yang dikonsumsi pasien adalah obat metformin dan glimepiride yang berfungsi untuk menurunkan resistensi insulin dan meningkatkan sekresi insulin. Ketidakpatuhan pasien dalam mengkonsumsi obat disebabkan oleh beberapa faktor, salah satunya yang memiliki pengaruh signifikan dalam penelitian ini adalah karena pasien lupa membawa obat saat berpergian yang berhubungan dengan regulasi gula darah pada pasien perempuan rawat jalan usia 45-59 tahun di Puskesmas Mojo, Pucang Sawu, dan Keputih Surabaya.

\section{ACKNOWLEDGEMENT}

Peneliti mengucapkan terimakasih kepada seluruh responden, Kepala Puskesmas Mojo, Pucang Sewu, dan Keputih Surabaya yang telah mengijinkan melakukan penelitian dan pengambilan data.

\section{REFERENSI}

1. Depkes RI. Pedoman pengendalian diabetes melitus dan penyakit metabolik (Direktorat Pengendalian Penyakit Tidak Menular, 2008).

2. Smeltzer, S. C. \& Bare, B. G. Buku Ajar Keperawatan Medikal-Bedah brunner \& suddarth Vol. 3 ed.8. (Buku Kedokteran EGC).

3. Tandra, H. Segala Sesuatu yang Harus Anda Ketahui Tentang DIABETES: Panduan Lengkap Mengenal dan Mengatasi Diabetes dengan Cepat dan Mudah (Edisi Kedua). (Gramedia Pustaka Utama, 2017).

4. International Diabetes Federation. Diabetes Atlas $7^{\text {th }}$ ed in (2015).

5. Kemenkes RI. Situasi dan Analisis Diabetes. Pusat Data dan Informasi Kementerian Kesehatan RI 2 (2014). doi:24427659 
6. Suiraoka, I. P. Penyakit Degeneratif: Mengenal, Mencegah, dan Mengurangi Faktor Risiko 9 Penyakit Degeneratif. (Nuha Medika, 2012).

7. Muflikhatin, S. K. \& Fakhrudin. Hubungan Antara Usia, Riwayat Keturunan Dan Pola Makan Dengan Kejadian Diabetes Mellitus Tipe 2 Di Ruang Flamboyan Rsud Abdul Wahab Sjahranie Samarinda. e-jurnal STIKES Muhammadiyah Samarinda 3, 1-14 (2015).

8. Sustrani, L. Hipertensi. (Gramedia Pustaka Utama, 2004).

9. Soegondo, S. Nefropati Diabetik, dalam Soegondo S, Soewondo P, \& Subekti I. Diabetes Mellitus Penatalaksanaan Terpadu (FKUI, 1995).

10. Srikartika, V. M., Cahya, A. D., Suci, R., Hardiati, W. \& Srikartika, V. M. Analisis Faktor Yang Memengaruhi Kepatuhan Penggunaan Obat Pasien Diabetes Melitus Tipe 2. J. Manaj. dan Pelayanan Farm. 6, 205-212 (2015).

11. Widodo, C. Anti Diabetik Oral Dengan Kadar Gula Darah Pasien Diabetes Program Pascasarjana Surakarta.

12. WHO. Adherence To Long-Term Therapies: Evidence For Action. World Health

Organization http://www.who.int/chp/knowledge/pu blications/adhe (2003).

13. Notoatmodjo, S. Metode Pengambilan Sampel. In: Metodologi Penelitian Kesehatan. (Rineka Cipta, 2014).

14. Kuntoro, A. Buku Ajar Manajemen Keperawatan. (Nuha Medika, 2010).

15. Donald E Morisky, A. A. M. K.-W. and H. J. W. Predictive Validity of A Medication Adherence Measure in an Outpatient Setting. J. Clin. Hypertens. 10, 348-354 (2008).

16. RI, D. Pedoman Praktis Memantau Status Gizi Orang Dewasa. (1994). Available at: http://perpustakaan.depkes.go.id/cgibi n/koha/opacdetail.pl\%3Fbiblionumber \%3D303.

17. Notoatmodjo, S. Pendidikan dan Perilaku Kesehatan. (Rineka Cipta, 2007).
18. Kurniawati, D. Faktor - Faktor Yang Berhubungan Dengan Pengontrolan Kadar Glukosa Darah Penderita Diabetes Mellitus Rawat Jalan Rumah Sakit Bhakti Wira Tamtama Semarang. (Universitas Negeri Semarang, 2007).

19. Toharin, S. N. R., Cahyati, W. H., Zainafree, I. Hubungan Modifikasi Gaya Hidup dan Kepatuhan Konsumsi Obat Antidiabetik Dengan Kadar Gula Darah Pada Penderita Diabetes Melitus Tipe 2 Di RS QIM. Unnes J. Public Heal. 4, 153161 (2015).

20. Ndraha, S. Diabetes Melitus Tipe 2 Dan Tatalaksana Terkini. Medicinus 27, 9-16 (2014).

21. Hannan, M. Analisis Faktor yang Mempengaruhi Kepatuhan Minum Obat pada Pasien Diabetes Melitus di Puskesmas Bluto Sumenep. J. Kesehat. Wiraraja Med. 47-55 (2013).

22. Rahmani, D. K. Monitoring Gula Darah dan Kepatuhan Minum Obat Dapat Menstabilkan Kadar Gula Darah pada Penderita Diabetes Mellitus Tipe II di Wilayah Ambarketawang Gamping Sleman Yogyakarta. (Sekolah Tinggi Ilmu Kesehatan 'Aisyiyah Yogyakarta, 2014).

23. Jamalludin, A. R. et al. Prevalens diabetis mellitus dan faktor-faktor yang berkaitan di kalangan penduduk Bukit Badong, Kuala Selangor. Buletin Kesihatan Masyarakat 1, (1994).

24. Damayanti \& Ayu . Pengaruh Pendidikan Kesehatan terhadap Tingkat Pengetahuan Pasien Diabetes Tipe 2 dalam Pencegahan Ulkus Kaku Diabetik di Poliklinik RSUD Panembahan Senopati Bantul. II, 1-10 (2015).

25. Gibson \& Ronald, F. Principles of Composite Material Mechanics. (Mc Graw Hill, 1994).

26. Goldberg AP \& Coon PJ. Diabetes Mellitus and Glucose Metabolism in Elderly. (Mc Graw Hill, 1994).

27. Mutmainah N, \& P. Hubungan Antara Kepatuhan Penggunaan Obat Dan Keberhasilan Terapi Pada Pasien Diabetes Mellitus Instalasi Rawat Jalan Di Rs X Surakarta. Eprints Univ. Muhammadiyah Surakarta 1-13 (2014). 
28. Rosyida, L., Priyandani, Y., Sulistyarini, A. \& Nita, Y. Kepatuhan Pasien Pada Penggunaan Obat Antidiabetes Dengan Metode Pill-Count Dan MMAS-8 Di Puskesmas Kedurus Surabaya. Jurbak Farmasu Komunitas 2, 36-41 (2015).

29. Subagiyo, R. A. Hubungan Tingkat Kepatuhan Minum Obat Dengan Kadar
Glukosa Darah Pada Pasien Diabetes Mellitus Di Klinik Anisah Demak. 508514 (2018).

30. Wakhidiyah, I. Z. Hubungan Antara Tingkat Pengetahuan, Sikap dan Keikutsertaan Penyuluhan Gizi dengan Perilaku Diit. J. Kesehat. Masy. 8, 113120 (2013). 